\title{
Impacts of COVID-19 and Nationwide Lockdown on River Ecosystems in Nepal
}

\author{
Deep Narayan Shah", Ram Devi Tachamo Shah' ${ }^{2 *}$, Deepak Rijal ${ }^{3}$ and Subodh Sharma ${ }^{2}$ \\ ${ }^{1}$ Central Department of Environmental Science, Tribhuvan University, Nepal \\ ${ }^{2}$ Aquatic Ecology Centre, Kathmandu University, Nepal \\ ${ }^{3}$ USAID Paani Program, Nepal
}

*Corresponding author: Ram Devi Tachamo Shah, 2Aquatic Ecology Centre, Kathmandu University, Dhulikhel 45200, Nepal.

To Cite This Article: Ram Devi Tachamo Shah, Impacts of COVID-19 and Nationwide Lockdown on River Ecosystems in Nepal. 2020 - 10(1). AJBSR. MS.ID.001474. DOI: 10.34297/AJBSR.2020.10.001474.

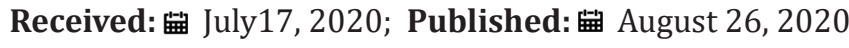

\section{Opinion}

Since January 2020, the novel virus of corona virus families, COVID-19, has been infecting people across the globe and today 213 countries have confirmed positive cases [1]. COVID-19 has caused a global pandemic with profound impacts on human life, environment, and freshwater biodiversity [2-4]. Corona virus was first diagnosed in Wuhan city of China early this year. World Health Organization (WHO) declared the outbreak as public health emergency of international concern on 30th January 2020 and then announced a new name for this disease as COVID-19 on 11thFebruary 2020 [4]. On 11th March 2020 declared it as pandemic. In Nepal, a first case was reported on 23rd January in 31 years old Nepalese who returned from Wuhan city on9thJanuary 2020. As of June 2020, above 15000 positive cases has been detected from 73 districts out of 77 districts of Nepal [5]. The country went into strict lockdown effective from 24th March to 15th June 2020 and slight ease later. All highways and streets are free from vehicles, factories are shut down; flights are grounded; rivers related activities like sand mining are completely halted. While people are lockdown inside with limited direct activities, the implications are serious and particularly dire for the poor and vulnerable people in the country.

Nepal is a land-linked country situated in the central part of the Himalayas between India and China. The country is rich in water resources and freshwater ecosystem their in. There are over 6000 rivers and streams flowing from high mountain to lowland regions forming diverse freshwater ecosystems. Flow conditions governing the transport of alluvial materials and timing of streambed inundation have considerable influence on biological productivity and diversity. Diverse communities of plants and animals depend on rivers, owing to the wide variety of shelter, breeding and feeding opportunities that river habitat provides. In Nepal, biodiversity is directly connected with livelihoods and economic well-being of the people. Fish and other aquatic animals are a key part of traditional food systems, which provide highly nutritious food of major social, cultural and economic significance.

The increased dependency of the growing population, especially dependent on river resources has emerged as a major threat to sustainable management of freshwater biodiversity. Apart from climate-induced action human interventions such as over extraction of aggregate materials from the river systems to meet growing demand for infrastructure development have contributed to alter riverbeds, hydraulics and water quality thereby affecting the quality of the habitats especially fishing ground. As a result, change in substrate composition pushing fish dependent species to higher risks. Constructions of high dams and weirs without a functional fish passage have posed additional threat to many species of fish and other aquatic animals, those with migrating behavior. Improper use of agro-chemicals has poised the habitats, which have directly affected the species of waterfowls and aquatic life. The exotic plant and animal species invaded in natural water has been another threat to wetlands distributed across temperature regimes in Nepal. Alien fish and freshwater prawn species introduced in Nepalese wetlands for aquaculture development show the rapid expansion of exotic species' habitat, and its significant potential negative effects on local biodiversity in the future [6] Over-fishing and fish poisoning have significantly reduced the food supply of fish-eating organisms. The cumulative effect of the above-mentioned human activities is 
already threatening the freshwater ecosystem and its biodiversity extensively.

Nepal has formulated a number of polices and legislative instruments to biodiversity conservation. Nepal as signatory of number of international conventions has been continuously working as per commitment made on those conventions. Unlike the policy provisions the aquatic biodiversity does not have yet been Nepal's priority programs and the outputs are not satisfactory, particularly for conservation. The scientifically credible research can greatly facilitate the process by understanding the effects of human impacts and developing the improved strategies with a more thorough knowledge of ecosystem processes. Despite all these challenges, the COVID-19 crisis has created an opportunity. Due to the national scale lockdown, human activities on the exploitation of rivers resources such as aggregate mining and fishing have decreased. Rivers from turbid waters returned into natural clear states as sand mining are stopped in major rivers. Fisher folks are not active in fishery due to lack of local and regional markets [authors' communications]. People have witnessed relatively large fishes in the rivers as these fishes are freely migrating upstream in spring season.

With significant decrease in human activities during countries lockdown across the globe, many polluted running water bodies turn to clear and clean with reappearance of many aquatic animals. For example: the Vembanad Lake (the longest freshwater lake in India), Grand Canal in Italy and the Ganges in India [7-10]. While in Nepal, due to lack of automated monitoring stations and other research infrastructures, there is lack of quantitative records halting real-time measurement [authors' observations]. A detail scientific study with establishment of water monitoring stations in different sections along a river would be imperative for understanding water quality dynamics in rivers. With lockdown, many people particularly the informal workers and laborers have returned from cities to rural areas. With extension of lockdown period, many of the low-income people are striving with reduced income and livelihood sources. In such times of pressures, natural resources act as supermarkets that serve food and nutrients. The local people have started fishing in the river for their consumption. Excessive fishing at community level would lead to extinction of highly valued species and this time of a year i.e., spring is critical as migratory fishes move upstream for spawning.

In terms of climate-induced hazards and earthquake, Nepal is one of the most vulnerable countries in the world. Increased massive inflow of migrant workers with pandemic has pushed the already miserable situation further down increasing the social vulnerability. The level of impacts of the hazards varies by households, socio-economic status and practical education. Apart from individual case studies and government record of returnees with their COVID-19 test results, studies are required to assess impacts of multiple hazards by different sections of the community. To fill this knowledge gaps a series of assessments are required to inform the development of the emergency action plans.

Community people become more vulnerable when exposed to multiple hazards. In the current situation, low income people striving food insecurity, socially excluded and people of minor and ethnic origins become more vulnerable likely to be trapped into vicious cycle of poverty. Community people tend to secure food security through common pool resources such as fishing, forest and river resources such as aggregate materials. 100 days lockdown has indicated that community people gradually shift to exploit natural resources for their livelihoods. More number of cases reporting where poaching of wild animals, overfishing and over extraction of gravel mining have increased. However, the intensity by regions and places and their implications on natural resource conservation is not known because of the lack of rapid assessments.

Except COVID-19 pandemic, Nepal has been periodically exposing to a variety of natural hazards, including floods, landslides, dry spell and inundation. The impacts are escalated when community compelled to face all in at once, the consequence would be to lose their lives, livelihood assets, infrastructure and the sources of income to support livelihoods. However, only very few studies are conducted that adequately reveal the extent and intensity of impacts that local community has been facing. Official records clearly read that there are mechanisms provisioned at all level of governments with mandate to deal with individual hazards. However, almost all the mechanism and networks are defunct mainly because of inadequate backstopping both in terms of human and finance resources. It is unclear the way it discharge services to community in need in times of urgency and therefore evaluation would be worthwhile to document the current practices, capacity and limitations.

\section{References}

1. Countries where COVID-19 has spread.

2. (2020a) WHO Report of the WHO-China Joint Mission on Coronavirus Disease 2019 (COVID-19).

3. Corlett RT, Primack RB, Devictor V, Maas B, Goswami VR, et al. (2020) Impacts of the coronavirus pandemic on biodiversity conservation. Biological Conservation 246: 108571.

4. (2020b) WHO Rolling updates on coronavirus disease (COVID-19).

5. (2020) Ministry of Health and Population (MoPH), Government of Nepal.

6. CSUWN (2011) Wetlands Invasive Alien Species Management Guidelines. CSUWN Project, Ministry of Forests and Soil Conservation, Kathmandu.

7. Pinder AC, Raghavan R, Britton JR, Cooke SJ (2020) COVID-19 and biodiversity: The paradox of cleaner rivers and elevated extinction risk to iconic fish species. Aquatic Conservervatuib: Marine and Freshwater Ecosystems 30: 1061-1062.

8. Mani KS (2020) The lockdown cleaned the Ganga More than 'Namami Gange' Ever Did. 
9. Clifford C (2020) The Water in Venice, Italy's Canals Is Running Clear amid the COVID-19 Lockdown.
10. Yunus AP, Masago Y, Hijioka Y (2020) COVID-19 and surface water quality: improved lake water quality during the lockdown. Science of Total Environment 731: 139012. 